\title{
Isolation, Selection and Determination of Endophytic Bacteria from Bamboo, Gamal, Tulsi, and Alamanda
}

\author{
Hermanu Triwidodo*1 Listihani $^{2}$ \\ ${ }^{1}$ Departement of Plant Protection, Faculty of Agriculture, IPB University \\ ${ }^{2}$ Study Program of Agrotechnology, Faculty of Agriculture and Business, Mahasaraswati University Denpasar \\ *Corresponding author. e-mail: petanimerdeka@gmail.com
}

\begin{abstract}
Endophytic bacteria have many benefits, including increasing plant growth by producing phytohormones, increasing the production of mineral absorption, nitrogen fixation, reducing damage due to weather changes and increasing plant resistance to disease. Based on the above, it is necessary to select endophytic bacteria from various plants to be used as biocontrol agents. This study aims to obtain endophytic bacterial isolates that have the potential as biocontrol agents and plant growth supporters from bamboo, Gamal, Tulsi, Lotus, and Alamanda. This research method includes sampling, endophytic bacteria isolation, hypersensitive, hemolysis, phosphate solvent, chitinolytic, proteolytic, and antagonist tests. Isolation of endophytic bacteria in 5 plants using 22 plant parts had a diversity of isolates. The isolated plant parts produced 1 to 7 isolates that had different morphology. The total isolates obtained were 59 isolates. In antagonistic observations, there was one isolate of endophytic bacteria that showed a clear zone when tested together with S. rolfsii, namely the isolate with code A24 from allamanda flower. From the data obtained, it is known that the endophytic bacterial isolates had an effect on inhibiting the growth of the pathogenic fungus $S$. roflsii, the endophytic bacterial isolates Consortium, A21 and the endophytic bacterial isolates A22 had no incidence of disease, while the bacterial isolates TOO (Bx) with an average disease incidence of $40 \%$ and $30 \%$ disease intensity. Meanwhile isolates A23, A24 and A25 had an average disease incidence ranging from $13.3 \%-26.6 \%$, while controls had the highest disease incidence, namely $53.3 \%$ and disease intensity $66.6 \%$.
\end{abstract}

Keyword: biocontrol agents, disease incidence, disease intensity, endophytic bacteria

\section{Introduction}

Endophytic bacteria live in plant tissues without harming the host plant and are active in these tissues [1]. Endophytic bacteria are found in various plant tissues, such as flowers, fruits, leaves, stems, and seeds or fruit in various plants [2]. Endophytic bacteria have many benefits, including increasing plant growth by producing phytohormones, increasing the production of mineral absorption, nitrogen fixation, reducing damage due to weather changes and increasing plant resistance to disease [3].

Endophytic bacteria can form colonies in tissues without harming the host. In one plant tissue, several types of endophytic microbes may be found [4]. The origin of the endophytic bacterial isolates, the type of bacteria and the root conditions of the host plant will cause different abilities to produce a secondary 
metabolite compound.

Endophytic bacteria as an biological control agents by producing antimicrobial compounds that are antagonistic, competition for space and nutrients against pathogens, competition for micronutrients such as iron, and producing siderophores, as well as causing host plants to become resistant to pathogen attack. In addition, some endophytic bacteria also produce antibiotic compounds such as phenazines, pyrolnitrin, pycocyanin, phloroglucianol and extracellular enzymes as well as pseudomonic acid. The diversity of endophytic bacterial species indicates that there are many possible ways of working against pathogens, which allows pathogens to produce antibiotic compounds against these endophytic bacteria [5].

The use of endophytic antagonists against other pathogens has several advantages when compared to the use of other antagonistic microbes, because endophytic microbes have been formed in plants which will remain and survive during plant development and continue to provide protection for plants. The presence of endophytic bacteria in plant tissue is more protected from external environmental factors. Several species of endophytic bacteria reported to have antagonistic properties against pathogens include: Bacillus subtilis, Ralstonia solanacearum, Pseudomonas fluorescens, P. putida, Agrobacterium radiobacter, A. tumifaciens, Erwinia herbicola, and Serratia marcescens. There are several ways of working of endophytic bacteria as biological control agents, namely producing antimicrobial substances, competition for space and nutrients, competition for micronutrients such as iron and production of siderophores, and can cause host plants to become resistant [5].

The selection of endophytic bacteria from various types of plants has not been done much. In addition, the results of the selection of endophytic bacteria obtained have also not been widely reported for the control of several important plant diseases. Based on the above, it is necessary to select endophytic bacteria from various plants to be used as biocontrol agents. This study aims to obtain endophytic bacterial isolates that have the potential as biocontrol agents and plant growth supporters from bamboo, Gamal, Tulsi, Lotus, and Alamanda.

\section{Materials and Methods}

\subsection{Sampling}

Samples were taken by selecting one plant that looked fertile and healthy even though the surrounding plants had symptoms due to biotic and abiotic factors. In this study, several types of plants were used as a source of endophytic bacterial isolates, namely bamboo , Gamal, Tulsi, Lotus, and Alamanda. In bamboo (Bambusa vulgaris), the upper and lower parts are taken by cutting directly. In the Gamal plant (Gliricidia sepium), the roots, stems and leaves were taken. In the Tulsi plant (Ocium tenuiflorum) several parts were taken, namely yellow pistil, green pistil, leaves, crown, and stem. Meanwhile, in Lotus (Nelumbo nucifera), only the leaves and stems were taken. In the Alamanda plant (Allamanda cathartica), the parts taken are roots, stems, and flowers.

\subsection{Endophytic Bacteria Isolation}

The plants that have been taken are then cleaned with running water and then weighed as much as $1 \mathrm{~g}$ as a sample. Furthermore, the sample that has been weighed will be the target for the isolation of endophytic bacteria. A total of $1 \mathrm{~g}$ of the prepared sample was then sterilized by immersing the sample in 
$2 \% \mathrm{NaOCl}$ for \pm 40 seconds to 1 minute, then immersed in sterile distilled water for \pm 1 minute twice. Then drained on a sterile tissue. After draining, the first thing to do is to rub the sample onto the surface of $20 \%$ TSA (Triptic Soy Agar) media as a control.

For isolation, carried out by the serial dilution method. The sterile sample was then ground using a sterile mortar in $10 \mathrm{ml}$ sterile distilled water. After the sample has been ground into suspension, $1 \mathrm{ml}$ is taken using a micropipette into a test tube containing $9 \mathrm{ml}$ of sterile distilled water as a 10-1 dilution, then $1 \mathrm{ml}$ of the dilution is taken back and transferred to the next tube as a 10-2 dilution, and so on. up to a dilution level of 10-3. After each transfer of the suspension to the next tube, mixing was carried out until the suspension became homogeneous using a vortex. In the 10-3 dilution, 1001 of the suspension was taken and poured onto the surface of $20 \%$ TSA, then spread using a spreading triangle. Furthermore, purification of each isolation was carried out.

After 7 days, isolates of endophytic bacteria generally produced one or more distinct colonies. Furthermore, each colony that was visually dissimilar was taken and transferred to $100 \%$ TSA media, each pure colony was recorded as an isolate of endophytic bacteria for further testing, including visual observation of the colony.

\subsection{Hypersensitivity Test}

Hypersensitivity test is carried out by preparing a liquid medium to be injected into leaves. One loop of bacterial colonies at the age of 48 hours was taken using a loop needle, then inserted into TSB (Triptic Soy Broth) media, then shaken until the media appeared opaque. As a control, TSB media was injected without prior bacterial inoculation. After all isolates were put into a glass bottle containing $2 \mathrm{ml}$ of TSB, the bottles were shaken using a shaker for 48 hours. After finishing shaking, the bacterial suspension was taken and each bottle was then injected into the leaves of the tobacco plant (Nicotiana tabacum). The leaves have previously written the isolate code to be injected. Injection using a $5 \mathrm{~mm}$ injection tool without using a needle. The injection device is directed at the junction of the leaf bones or at the leaf bone below the surface, then the top of the leaf surface is held using one finger to apply pressure, so that when the suspension is injected, the suspension fluid will enter the xylem flow. When doing the injection, it is necessary to ensure that there is no tearing of the leaves or leakage of the suspension out of the tissue. Observations for hypersensitivity reactions were carried out after 48 hours. Isolates that cause this reaction will produce necrosis in the injected leaves.

\subsection{Hemolysis Test}

Hemolysis test or blood agar test was conducted to determine whether the isolates used had the ability to hemolyze human and mammalian blood. The test used blood agar media obtained from the Laboratory of the Faculty of Veterinary Medicine, Bogor Agricultural University. Each 48-hour-old endophytic bacterial isolate was taken using an osseous needle, then affixed in the form of a dot using a sterile toothpick. Furthermore, observations were made on the clear zone produced by isolates of endophytic bacteria. A negative result is obtained if there is no clear zone, meaning that the bacteria are safe for humans and other mammals. On the other hand, if there is a clear zone, it means that the bacteria can hemolyze the blood of humans and mammals. The isolates selected using the media were isolates that had been tested for hypersensitivity and did not show a necrotic reaction on tobacco leaves. The isolates selected using the media were isolates that had been tested for hypersensitivity and did not show a necrotic reaction on tobacco leaves. 


\subsection{Phosphorous Solvent Test}

Phosphorous solubilizing bacteria are generally present in the soil, because their role is to dissolve $\mathrm{P}$ which is not available to plants because it is bound to Fe-phosphate and Al-phosphate in acidic soils or $\mathrm{Ca}_{3}\left(\mathrm{PO}_{4}\right)_{2}$ on alkaline soil. Microbes are known to dissolve $\mathrm{P}$ so that it is readily absorbed by plants [6]. Therefore, in this practicum, the selected endophytic bacteria were also tested whether they have the same ability, even though they are permanent in plant tissue. The media used for the phosphate solvent test is Pikovskaya agar media with the following components; $\mathrm{Ca}_{3}\left(\mathrm{PO}_{4}\right)_{2} 5 \mathrm{gr},\left(\mathrm{NH}_{4}\right)_{2} \mathrm{SO}_{4} 0.5 \mathrm{gr} ; \mathrm{NaCl} 0.2 \mathrm{~g}$; $\mathrm{MgSO}_{4} .{ }_{7} \mathrm{H}_{2} \mathrm{O} 0.1 \mathrm{~g}$; $\mathrm{KCl} 0.2 \mathrm{~g}$; Glucose $10 \mathrm{~g}$; yeast extract $0.5 \mathrm{~g}$; agar $20 \mathrm{~g}$; $\mathrm{MnSO}_{4}$ and $\mathrm{FeSO}_{4}$ a little, $1000 \mathrm{ml}$ of distilled water [7]. The isolates selected using this medium were isolates that had been tested for hypersensitivity and did not show a necrotic reaction on tobacco leaves.

\subsection{Chitinolytic Test}

Some bacteria are able to degrade chitin, a polysaccharide with a linear polymer form composed of -1,4-N-acetyl-glucosamine monomer. Chitin can be degraded in the presence of the extracellular enzyme chitinase in bacteria. The chitinolytic activity can be induced by growing bacterial isolates on media containing chitin as carbon. A positive reaction will occur in the presence of a clear zone around the bacterial colonies on chitin media [8]. This medium was made by adding $0.4 \%$ chitin to NA (Nutrient Agar) media, then streaking the selected endophytic bacterial isolates at the age of 48 hours on the media. The isolates selected using this medium were isolates that had been tested for hypersensitivity and did not show a necrotic reaction on tobacco leaves.

\subsection{Proteolytic Test}

To test the proteolytic activity of selected bacterial isolates, SMA (Skim Milk Agar) media was used, namely by adding $2 \%$ skim milk to NA media. After the media solidified, then the colonies from each isolate were taken using a ose needle to be scratched onto the SMA media. Observations were made on the presence of a clear zone indicating the presence of proteolytic activity. The isolates selected using the media are isolates that have been tested using blood agar.

\subsection{Antagonist Test}

In vitro. Antagonist test was carried out to obtain endophytic bacterial isolates that have the potential to have antagonistic mechanisms against pathogens. In this study, the pathogenic fungus Sclerotium rolfsii isolated from the collection of the Plant Disease Laboratory, Faculty of Agriculture, Udayana University was used. The antagonist test was carried out on isolates of endophytic bacteria that did not undergo hemolysis on the blood agar test. The media used is NA (Nutrient Agar). Hyphae from S. rolfsii were taken using a cork borer under sterile conditions, then placed in the middle of the NA medium. Furthermore, at a distance of $2 \mathrm{~cm}$ from the colony of S. rolfsii, endophytic bacterial isolate was streaked.

In planta. Endophytic bacterial antagonist test against the fungus $S$. roflsii in planta aims to determine the ability of endophytic bacteria antagonist against pathogenic fungi. The test was carried out by growing bacteria in $100 \mathrm{~mL}$ of 100\% TSB media and then shaking it for 48 hours. After 48 hours, the cucumber seeds that have been surface sterilized using $70 \%$ alcohol for 40 seconds, Tween 20 for 1 minute, and rinsed with distilled water at $50^{\circ} \mathrm{C} 3$ times are put into bacterial suspension. The seeds are soaked for 1 
hour, then grown on soil media and sterile fertilizer with a ratio of 2:1 which had previously been sprayed with fungal suspension with a hand sprayer. The fungus $S$. roflsii in a petri dish was dissolved in sterile water, then put into a hand sprayer and sprayed onto the growing media. The variables observed were disease incidence and disease intensity.

\subsection{Growth Test}

The Test of the Effectiveness of Endophytic Bacteria on the growth of Wuku Cucumber Seeds aims to determine the ability of endophytic bacteria to increase plant growth. The test was carried out by growing bacteria in $100 \mathrm{~mL}$ of $100 \%$ TSB media and then shaking it for 48 hours. After 48 hours, the cucumber seeds that had been surface sterilized using $70 \%$ alcohol for 40 seconds, Tween 20 for 1 minute, and rinsed with distilled water at $50^{\circ} \mathrm{C} 3$ times were put into bacterial suspension. Seeds were soaked for 1 hour, then grown in soil and sterile fertilizer in a 2:1 ratio. The observed variables were plant height and root height.

\section{Results and Discussion}

\subsection{Endophytic Bacteria Isolation}

Isolation of endophytic bacteria in 5 plants using 22 plant parts had a diversity of isolates. The isolated plant parts produced 1 to 7 isolates that had different morphology. The total isolates obtained were 59 isolates. The isolates obtained were mostly from gamal leaves at a dilution of 10-3 as many as 7 isolates, tulsi leaves at a dilution of 10-2 as many as 6 isolates, tulsi stems at a dilution of 10-3 as many as 6 isolates, gamal roots at a dilution of 10-5 as many as 5 isolates, crown lotus with a dilution of 10-3 as many as 4 isolates, parts of the Alamanda plant produced 5 isolates and other plant parts produced an average of 1 to 3 isolates.

Table 1.

Hypersensitivity test results of tested endophytic bacteria isolates

\begin{tabular}{llc}
\hline Isolate used & Isolate source & Results \\
\hline G01 & Leaf gamal & - \\
G02 & Leaf gamal & + \\
G03 & Leaf gamal & + \\
G04 & Leaf gamal & + \\
G05 & Leaf gamal & + \\
G06 & Leaf gamal & - \\
G11 & Leaf gamal & + \\
R07 & The bottom of the bamboo shoots & + \\
R08 & The bottom of the bamboo shoots & + \\
R09 & The bottom of the bamboo shoots & + \\
R10 & The bottom of the bamboo shoots & - \\
K & Control TSB & - \\
T01 & Stem tulsi & - \\
T02 & Stem tulsi & Page
\end{tabular}




\begin{tabular}{lll}
\hline T03 & Stem tulsi & - \\
T04 & Stem tulsi & - \\
T05 & Stem g tulsi & - \\
T06 & Leaf tulsi & - \\
T07 & Leaf tulsi & - \\
T08 & Leaf tulsi & - \\
T09 & Leaf tulsi & - \\
T10 & Leaf tulsi & - \\
T11 & Leaf tulsi & - \\
T12 & Stem tulsi & - \\
T13 & Stem tulsi & - \\
T14 & Stem tulsi & - \\
K & Control TSB media & - \\
A21 & Root allamanda & - \\
A22 & Flower alamanda & - \\
A23 & Flower alamanda & - \\
A24 & Flower alamanda & - \\
A25 & Leaf alamanda & - \\
K & Control TSB media & - \\
\hline
\end{tabular}

\subsection{Hypersensitivity Test}

The isolates obtained from gamal leaves and bamboo mostly showed hypersensitivity reactions, while isolates from tulsi and alamanda plants did not show hypersensitivity reactions (Table 1). Leaf indicator plants that show a hypersensitivity reaction will first show symptoms of a brownish halo, then necrosis occurs on the surface until the leaves are torn. If a hypersensitivity reaction occurs, it is suspected that the isolate is a pathogen.

After being tested for hypersensitivity to tobacco leaves, bacteria that have pathogenic properties cause tobacco leaves to turn brown in the area of bacterial entry. This reaction is most clearly observed 48 hours after injection. Hypersensitivity reaction is a rapid and localized program of cell death. This reaction occurs in infected plants upon introduction of the pathogen and along with it, is an attempt to inhibit the growth of the pathogen. The induction of hypersensitivity and pathogenicity reactions is influenced by the hrp gene which is commonly found in plant pathogenic gram-negative bacteria [9]. Endophytic microbes are microbes that live in plant tissues for a certain period and are able to live by forming colonies in plant tissues without harming their hosts [10].

\subsection{Hemolysis, Phosphorous Solvent and Chitinolytic Tests}

Hemolysis test aims to classify certain microorganisms, by observing the ability of bacterial colonies to induce hemolysis when grown on blood agar (blod agar). The results showed that there were 14 isolates that succeeded in destroying red blood cells on agar agar, thus showing hemolysis (Table 2). Some of these isolates were thought to be pathogenic bacteria in mammals and not classified as endophytic bacteria.

Endophytes support increased growth through a number of the same mechanisms. These include dissolving phosphate, IAA hormone, and production of siderophore a [11,12,13,14]. Endophytes also help in the availability of essential elements for plants [15]. In addition, other beneficial effects associated with 
endophytes are assisting in osmotic regulation, stomata, morphological modification (as in roots), increased mineral absorption and changes in nitrogen accumulation and metabolism [16].

Table 2.

Test Results for Blood Agar, Phosphorous Solvent and Chitinase

\begin{tabular}{clccc}
\hline Isolate used & Isolate source & $\begin{array}{c}\text { Blood } \\
\text { Test }\end{array}$ & $\begin{array}{c}\text { Agar } \\
\text { Phosphate } \\
\text { Solvent Test }\end{array}$ & $\begin{array}{l}\text { Chitinase } \\
\text { Test }\end{array}$ \\
\hline T00 $(\mathrm{BX})$ & Stem tulsi & - & - & - \\
T01 & Stem tulsi & + & - & - \\
T02 & Stem tulsi & + & - & - \\
T03 & Stem tulsi & + & - & - \\
T04 & Stem tulsi & + & - & - \\
T05 & Stem tulsi & + & - & - \\
T06 & Leaf tulsi & + & - & - \\
T07 & Leaf tulsi & + & - & - \\
T08 & Leaf tulsi & + & - & - \\
T09 & Leaf tulsi & + & - & - \\
T10 & Leaf tulsi & + & - & - \\
T11 & Leaf tulsi & + & - & - \\
T12 & Stem tulsi & + & - & - \\
T13 & Stem tulsi & + & - & - \\
T14 & Stem tulsi & + & - & - \\
A21 & Root allamanda & - & - & - \\
A22 & Flower alamanda & - & - & - \\
A23 & Flower alamanda & - & - & - \\
A24 & Flower alamanda & - & - & - \\
A25 & Leaf alamanda & - & - & - \\
\hline
\end{tabular}

\subsection{Proteolytic Test}

Isolates that have passed the blood agar test, phosphate solvent test and chitinase test have been tested again in proteolytic testing. Of the 6 isolates tested proteolytically, only 1 isolate showed positive results, namely isolate A23 obtained from the flower of alamanda (Figure 1). The clear zone formed on isolate A23 indicated that the endophytic bacterial isolate was able to convert long protein chains into smaller chains called peptides.

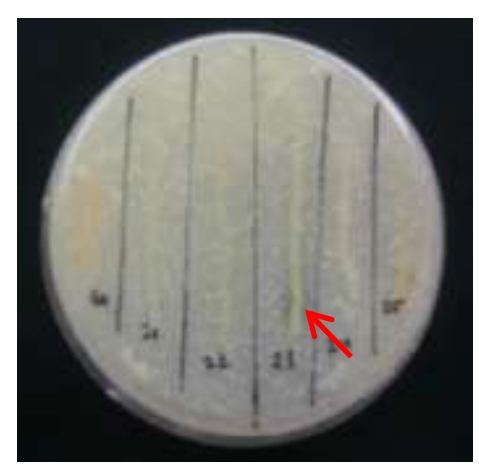


Figure 1

Clear zone in the proteoitic test of isolates from tulsi and allamanda (indicated by red arrows)

\subsection{Antagonist Test}

\subsubsection{In vitro}

In antagonistic observations, there was one isolate of endophytic bacteria that showed a clear zone when tested together with $S$. rolfsii, namely the isolate with code A24 from allamanda flower (Figure 2).

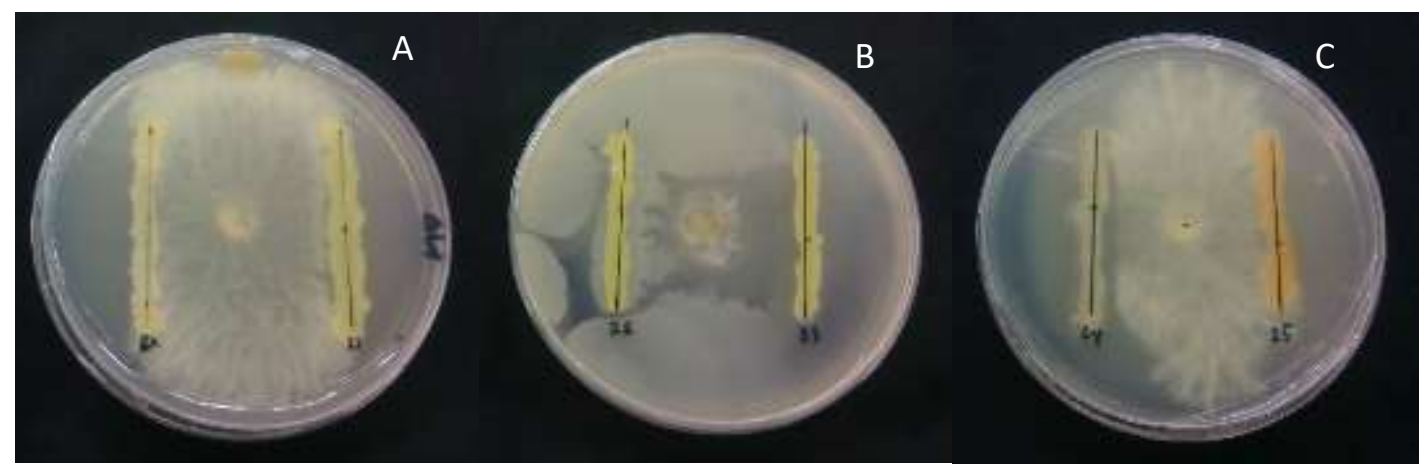

Figure 2

Antagonistic test of several bacterial isolates against $S$. rolfsii on NA media. A= isolates T00 and A21, B= isolates A22 and A23, C= isolates A24 and A25

\subsubsection{In planta}

The results of the antagonist test between isolates of endophytic bacteria and the pathogenic fungus S. roflsii obtained data on the incidence and intensity of disease (Table 3). From the data obtained, it is known that the endophytic bacterial isolates had an effect on inhibiting the growth of the pathogenic fungus S. roflsii, the endophytic bacterial isolates consortium, A21 and the endophytic bacterial isolates A22 had no incidence of disease, while the bacterial isolates T00 (Bx) with an average disease incidence of $40 \%$ and $30 \%$ disease intensity. Meanwhile isolates A23, A24 and A25 had an average disease incidence ranging from $13.3 \%-26.6 \%$, while controls had the highest disease incidence, namely $53.3 \%$ and disease intensity $66.6 \%$ [17]. Hallmann stated that endophytic bacteria have the ability to protect plants from soil-borne pathogens. Endophytic bacteria can colonize root cortex tissue and produce metabolites that suppress pathogens to induce plant resistance. Antibiotic compounds produced by antagonistic bacteria can act directly as bactericides against pathogenic bacteria and inducer agents (elicitor) of plant resistance to disease [18]. Endophytic bacteria can inhibit the growth of pathogenic fungi in several ways, namely by 
producing siderophores and producing metabolites that are toxic to pathogenic fungi $[19,20]$. Based on research by Chen [21], secondary metabolites produced by Bacillus are surfactin, bacillomycin, fengycin, peptide, and iron siderophore bacilibactin, which have antifungal activity. Phenazine compounds as secondary metabolites by Pseudomonas chlororaphis bacteria act as antagonists and antifungal activities against the fungal pathogen Sclerotium sp. [22]. The secondary metabolite compound produced by Bulkhoderia bacteria is a liquid hydrocarbon cyclic terpene and was identified as a cyclohexene compound 1-methyl-4-(1-methylethenyl) and also a 4-flavanone compound (4H-1-Benzopyran-4-one, 2, 3- dihydro2-phenyl) both volatile compounds were reported to have antifungal activity [23].

Table 3.

Average incidence and intensity of disease in the in planta antagonist test between isolates of endophytic bacteria and the fungal pathogen $S$. rolfsii

\begin{tabular}{ccc}
\hline Endophytic bacteria isolate & Disease incidence $(\%)$ & Intensity $(\%)$ \\
\hline Consortium & - & - \\
T00 $(\mathrm{Bx})$ & $\mathbf{4 0}$ & $\mathbf{3 0}$ \\
A21 & - & - \\
A22 & - & - \\
A23 & $\mathbf{1 3 , 3}$ & $\mathbf{1 3 , 3}$ \\
A24 & $\mathbf{2 6 , 6}$ & $\mathbf{2 3 , 3}$ \\
A25 & $\mathbf{2 6 , 6}$ & $\mathbf{2 6 , 6}$ \\
Control & $\mathbf{5 3 , 3}$ & $\mathbf{6 6 , 6}$ \\
\hline
\end{tabular}

\subsection{Endophytic Bacteria Test Against Wuku Cucumber Plant Growth}

Endophytic bacterial isolates had an effect on the growth of wuku cucumber plants. Cucumber seeds were soaked with each suspension of endophytic bacteria and then planted in sterile soil and after 2 weeks of observation, the height of cucumber plants treated with endophytic bacteria was higher than the control treatment (Table 4). Consortium bacterial isolates, A23 and A24 most affected the growth of tomato plants with tomato plant height of $24.2 \mathrm{~cm}$ for consorcium, $22.6 \mathrm{~cm}$ for isolate A23 and $22 \mathrm{~cm}$ for isolate A24, endophytic bacterial isolate A25 had the lowest effect on cucumber growth with plant height reached $19.5 \mathrm{~cm}$, while the control treatment of cucumber plant height was only $15.1 \mathrm{~cm}$.

Table 4

Average total length and plant length of Wuku Cucumber after being treated with endophytic bacteria

\begin{tabular}{|c|c|c|c|}
\hline \multirow[t]{2}{*}{ Bacteria isolate } & \multicolumn{2}{|c|}{ Average rice plant length $(\mathrm{cm})$} & \multirow[b]{2}{*}{ Plant height $(\mathrm{cm})$} \\
\hline & Germination (\%) & Root length $(\mathrm{cm})$ & \\
\hline Consortium & 100 & 5,8 & 24,2 \\
\hline T00 (Bx) & 80 & 4,1 & 21,1 \\
\hline A21 & 93 & 3,7 & 20,8 \\
\hline A 22 & 73 & 4,1 & 20,2 \\
\hline A 23 & 100 & 4,4 & 22,6 \\
\hline A 24 & 93 & 4,6 & 22 \\
\hline A 25 & 87 & 3,7 & 19,5 \\
\hline Control & 60 & 3,2 & 15,1 \\
\hline
\end{tabular}


In addition to affecting the height of the cucumber plant, the endophytic bacterial isolates also affected the root length of the cucumber plant. The treatment of the consortium's endophytic bacteria isolates, A23 and A24 gave the maximum effect on the length of the cucumber plant, each with an average root length of $5.8 \mathrm{~cm}, 4.4 \mathrm{~cm}$ and $4.6 \mathrm{~cm}$, while for the control treatment the root length of the cucumber plant $3.2 \mathrm{~cm}$ shorter than the length of cucumber roots treated by other bacterial isolates. The effect of increasing the growth of cucumber plants after being treated with endophytic bacteria is thought to be due to the presence of growth regulatory compounds produced by endophytic bacteria. Endophytic bacteria are reported to be able to increase plant growth, decompose pathogenic cell walls, and inhibit pathogen growth by producing antimicrobial compounds such as siderophores [24]. The interaction of endophytic bacteria and plants is a form of symbiosis. The symbiosis between plants and endophytic bacteria is neutral, mutualism or commensalism [5]. Mutualism symbiosis between endophytic bacteria and plants, in this case endophytic bacteria get nutrients from plant metabolism and protect plants against pathogens, while plants get nutritional derivatives and active compounds needed during their life [25].

The increase in plant growth by treatment of endophytic bacteria is thought to be because endophytic bacteria can increase nitrogen fixation, photosynthetic activity and the production of indole acetic acid (IAA) [26,27]. Nongkhlaw [28] reported that endophytic bacteria were able to increase plant growth because they produced important components for plant growth, such as mineral phosphate, acid phosphatase activity, and the presence of 1-aminocyclopropane-1-carboxylic acid (ACC) deaminase. In addition, the interaction of endophytic bacteria with plants can produce elicitors in the induction of resistance, which can produce lipopolysaccharides that act as elicitors in the induction of resistance that specifically bind to receptors on the surface of plant cells [29]. Endophytic bacteria are known to be able to bind nitrogen nutrients and dissolve phosphate, thereby reducing the use of artificial fertilizers [30]. Eliza [31] reported that endophytic bacteria isolated from the roots of corn plants can stimulate the growth of cucumber and banana plants

\section{Conclusion}

The treatment of the Consortium's endophytic bacteria isolates, A23 and A24 gave the maximum effect on the length of the cucumber plant, each with an average root length The effect of increasing the growth of cucumber plants after being treated with endophytic bacteria is cause the presence of growth regulatory compounds produced by endophytic bacteria. Endophytic bacteria are reported to be able to increase plant growth and inhibit pathogen growth by producing antimicrobial compounds such as siderophores

\section{References}

[1] Barac T, Taghavi S, Borremas B, Provoost A, Oeyen L, Colpaert J V, Vangronsveld J, Lelie D V. (2004). Enggineered endophytic bacteria improve phytoremediation of water-soluble, volatile, organic pollutans. Nature Biotech, 22.

[2] Hung P Q dan Annapurna K. (2004). Isolation and characterization of endhopytic bacteria in soybean(Glycine sp.) Omontie, 12, 92-101.

[3] Zinniel D K, Lambrecht P, Harris N B, Feng Z, Kuczmarski D, Highley P, Ishimaru C A, Arunakumari A, Barletta R G, Vidarel A K. (2002). Isolation and characterization of endophytic colonizing bacteria from agronomic crops and prairie plants. Applied and Environmental Microbiology, 8(5). 
[4] Strobel, G. A. \& B. Daisy. (2003). Bioprospecting for Microbial Endophytes and Their Natural Products. Microbiology and Molecular Biology. 419-502.

[5] Bacon CW, Hinton DM. (2006). Bacterial endophytes: the endophytic niche, its occupants, and its utility. Di dalam: Gnanamanickam SS, editor. Plant-Associated Bacteria. Netherland: Springer

[6] Cunningham,JE., and C. Kuiack. (1992). Production of citric and oxalic acid and solubilization of calsium phosphate by Penicillium bilail. Appl. Environ. Microbial. 58, 1451-1458.

[7] Suliasih dan Rahmat. (2007). Aktivitas Fosfatase dan Pelarutan Kalsium Fosfat oleh beberapa Bakteri Pelarut Fosfat. Biodiversitas, 8(1), 23-26.

[8] Herdyastuti K, Raharjo TJ, Mudasir, dan Matsjeh S. (2009). Chitinase and Chitinolytic Microorganism: Isolation, Characterization and Potential. Indo J. Chem, 9(1), 37-47.

[9] Wahyudi AT, Meliah S, Nawangsih AA. (2011). Xanthomonas oryzae pv. oryzae Bakteri Penyebab Hawar Daun pada Padi: Isolasi, Karakterisasi, dan Telaah Mutagenesis dengan Transposon. Makara Sains, 15 (1), 89-96.

[10] Radji. M. (2005). Peranan Bioteknologi Dan Mikroba Endofit Dalam Pengembangan Obat Herbal. Majalah Ilmu Kefarmasian, 1, 113 - 126.

[11] Verma, S. C., Singh, A., Chowdhury, S. P., and Tripathi, A. K. (2004). Endophytic colonization ability of two deep-water rice endophytes, Pantoea sp. and Ochrobactrum sp. using green fluorescent protein reporter. Biotechnol. Lett, 26, 425-429.

[12] Wakelin I, Mims, C., Dockrell, H. M., Roitt, Derek, Zuckerman. (2004). Medical Microbiology.5th ed. Philadelphia: Elsevier.

[13] Lee J.Y., Hwang W. I., Lim S.T. (2004). Antioxidant and anticancer of organic extracts from Platycodon grandiflorum A. De Candolle roots. Journal of Ethnopharmacology, 93, 409-15.

[14] Costa, J.M., Loper, J.E. (1994). Characterization of siderophore production by the biological-control agent Enterobactercloacae. Mol. Plant-Microbe Interactions J., 7, 440-448.

[15] Pirttila, A. M., Joensuu, P., Pospiech, H., Jalonen, J., and Hohtola, A. (2004). Bud endophytes of Scots pine produce adenine derivatives and other compounds that affect morphology and mitigate browning of callus cultures. Physiol. Plantarum, 121, 305-312.

[16] Compant S, Duffy B, Nowak J, Clement C, Barka EA. (2005). Use of plant growth-promoting bacteria for biocontrol of plant diseases: Principles, Mechanisms of Action and future prospects. Applied and Environmental microbiology, 71(9).

[17] Hallmann, J. (2001). Plant Interaction with Endophytic Bakteria. In: Jeger, M.J. And spence, N.J., editor. Biotic Interaction in Plant-Pathogen Associations. CAB Internasional. P. 87-119.

[18] Lyon, G. (2007). Agents that Can Elicit Induced Resistance. In: Walters, D.Newton, A., Lyon, G. Editor. Induced Resistance for Plant Defence: Sustainable Approach to Crop Protection. Blackwell Publishing. pp.9-30.

[19] Kloepper JW, Leong J, Tientze M, Schroth MN. (1980). Enhanced plant growth by siderophores produced by plant growth promoting rhizobacteria. Nature. 286, 885-886.

[20] Schnider-Keel U, Seematter A, Maurhofer M, Blumer C, Duffy BK, Gigot-Bonnefoy C, Reimmann C, Notz R, Defago G, Hass D \& Keel C. (2000). Autoinduction of 2,4-diacetylphoroglucinol biosynthesis in the biocontrol agent Pseudomonas fluorescens $\mathrm{CHA} 0$ and repression by the bacterial metabolites salicylate and pyoluteorin. Journal of Bacteriology. 182, 1.215-1.225.

[21] Chen XH, Koumoutsi A, Scholz R, Borriss R. (2009). More than Anticipated - Production of Antibiotics and Other Secondary Metabolites by Bacillus amyloliquefaciens FZB42. J Mol Microbiol Biotechnol 16, 14-24.

[22] Poritsanos NJ. (2005). Molecular Mechanisms Involved in Secondary Matabolite Production and Biocontrol of Pseudomonas chlorophis PA23. [thesis]. The University of Manitoba: Canada.

[23] Elshafie HS, SA Bufo, R Racioppi, I Camele. (2013). Biochemical Characterizatio of Volatile Secondary Metabolites Produced by Burkholderia gladioli pv. agaricicola. International Journal of Drug Discovery. 5(1), 181-184. 
[24] Chandrashekhara. 2007. Endophytic Bacteria from Different Plant Origin Enhance Growth and Induce Downy Mildew Resistance in Pearl Millet. http://www.scialert.net/qredi rect.php?doi=ajppaj.2007.1.11\&linkid=pdf - similarby-SN-Chandrashekhara-2007.

[25] Simarmata, R. (2007) . Isolasi Mikroba Endofitik dari Tanaman Obat Sambung Nyawa (Gynura Procumbens) dan Analisis Potensinya sebagai Antimikroba. Berk. Penel. Hayati, 13, 1-6.

[26] Duangpaeng A, Phetcharat P, Chanthapho S, Boonkantong N, Okuda N. (2012). The study and development of endophytic bacteria for enhancing organic rice growth. Procedia Engineering, 32, $172-176$.

[27] Lopez BR, Tinoco-Ojanguren C, Bacilio M, Mendoza A, Bashan Y. (2012). Endophytic bacteria of the rock-dwelling cactus Mammillaria fraileana affect plant growth and mobilization of elements from rocks. Environmental and Experimental Botany, 81, 26-36.

[28] Nongkhlaw FM, Joshi SR. (2014). Epiphytic and endophytic bacteria that promote growth of ethnomedicinal plants in the subtropical forests of Meghalaya, India. Rev Biol Trop 62, (4),1295-308.

[29] Reitz M, Rudolph K, Schroeder I, Hoffmann- Hergarten S, Hallmann J, Sikora RA. (2000). Lipopolysccharides of Rhizobium etli G12 act in potato root as an inducing agent of systemic resistance to infection by the cyst nematode Globodera pallida. Applied and Environ. Microbiol, 66 (8), 3515- 3518.

[30] Pedraza RO, Ar Mata, Ml Xiqui, Be Baca. 2004. Aromatic amino acid aminotransferase activity and indole-3-acetic acid production by associative nitrogen-fixng bacteria. FEMS Microb. Letters. 233: $15-21$.

[31] Eliza. 2004. Pengendalian layu fusarium pada pisang dengan bakteri perakaran graminae. [Tesis]. Bogor. Institut Pertanian Bogor. 